\title{
TIC Regimen
}

National Cancer Institute

\section{Source}

National Cancer Institute. TIC Regimen. NCI Thesaurus. Code C63726.

A regimen consisting of paclitaxel, ifosfamide, mesna and carboplatin used as salvage

therapy for the treatment of advanced-stage testicular cancer; also used for the treatment of unresectable and recurrent squamous cell head and neck cancer. 